\title{
PEDAGOGICAL TECHNOLOGIES IN MUSIC EDUCATION AS A FACTOR OF DEVELOPMENT OF THE INTEGRAL PERSONALITY
}

\author{
Marina Marchenoka \\ Rezekne Academy of Technologies, Latvia
}

\begin{abstract}
Music like any other art helps the individual explore the world, develops the individual's emotional sphere, building fundamentals for systematisation and classification of phenomena, algorithms of creative thinking on the basis of the perception and analysis of music artistic characters, thus defining development of students' memory, fantasy and imagination, stimulating them to search for unusual solutions of problems. The development of these abilities is indispensable in any sphere of human activity and - what is the most important - gives a possibility for individual's self-realisation. Therefore the main task of music education is development of the complete personality, based on the needs and demands of the modern society. Solution of this task requires reviewing of the music educational process, modernisation of the ways of realisation of the educational content, ensuring creation of new teaching forms, methods, means and technologies.
\end{abstract}

Keywords: pedagogical technologies, music educational process, development of a personality, activity, model.

\section{Introduction}

"A bad teacher presents the truth, a good teacher helps to find it" Adolph Diesterweg

Due to the modification of the main paradigm of the modern education directed towards educating and upbringing of a creative, tolerant, sociable individual, understanding values of the world and national culture, having own active life position, i.e. education of the consistent individual, it is necessary to reconsider the entire pedagogical process and to transit to a new content of education, which would correspond to the today's needs of the social and economic development of the society.

The main reasons why the new content is necessary are:

- the need in increase of motivation and intensification of students' learning and cognitive activity;

- the low level of the individual's socialisation in the dynamically changing society; 
- the necessity to introduce a systematically active approach into the study process;

- replacement of the inefficient verbal way of knowledge transfer (psychologists acknowledge that a student is capable to assimilate not more than $36 \%$ of verbal information);

- $\quad$ the possibility to plan a technological chain of methods, organisational forms of interaction between a student and a teacher, being a guarantee of stable results.

The sphere of music education has been conservative for a long time and almost no technological innovations have been used in it. Mostly it is related to the special features of the music education, which is addressed to the individual's emotions and inner world, and its development is "unique, inimitable and cannot be technologically described” (Шакурова, 2016).

Music like any other art helps the individual explore the world, develops the individual's emotional sphere, building fundamentals for systematisation and classification of phenomena, algorithms of creative thinking on the basis of the perception and analysis of music artistic characters, thus defining development of students' memory, fantasy and imagination, stimulating them to search for unusual solutions of problems. The development of these abilities is indispensable in any sphere of human activity and - what is the most important - gives a possibility for individual's self-realisation. Therefore the main task of music education is development of the complete individual, based on the needs and demands of the modern society. Solution of this task requires reviewing of the music educational process, modernisation of the ways of realisation of the educational content, ensuring creation of new teaching forms, methods, means and technologies.

\section{Aims of the research:}

- $\quad$ to do a theoretical analysis of the evolution of the concept "pedagogical technology" and to define principal methodological principles of assessment of the pedagogical activity;

- $\quad$ to examine pedagogical technologies in the music educational process and work out a processual model of pedagogical technologies in the music educational process as an activity.

Methodology of the research: theoretical analysis of scientific literature about the problem of the research, modelling, interpreting.

Theoretical basis of the research: concepts of pedagogical technologies (John Amos Comenius, N. Crowder, V. Bespalko, G. Selevko), activity theory (L. Vygotsky, S. Rubinstein, A. Leontyev), activity cycle (Z. Chehlova). 


\section{Evolution of the concept "pedagogical technology"}

“Technologization" of pedagogical activity had started early before the moment, when the largest part of pedagogues, scientists and practitioners realised objectivity of the processes.

The term "Technology" appeared in Ancient Greece and it consists of two parts: "techne" - art, skill, mastery and "logia" - the study of. If we translate it word for word, the word "technology" means a study of skill (Михайленко, 2011). For those times, it meant an art of an artisan who was practicing it in producing various objects under guidance of a mentor. Pedagogues of Ancient Egypt, Greece and Babylon noticed that repetitiveness of operations in creation of any values (producing household objects, or interior objects, etc.) helps develop necessary apprentice's skills. Thus, famous Greek philosopher and pedagogue Socrates owing to his forethought and logical influence on the disciples "provoked their intellectual activity, inducing them to see the deep core of the discussed problem behind the outer ease of the issue" (Фохт, 1998). Later the concept "technology" came widely into use also in other spheres. As British psychologist and expert in the sphere of creative thinking Edward de Bono (Edward de Bono, 1933) says, technology is a process "of production of something useful on the basis of knowledge application” (Эдвард де Боно, 2005).

Quite natural is the fact that Technology and Pedagogy as sciences emerged in the same historical period, because organisation of mass-production required for mass-education. A fundamental of mass education was developed by John Amos Comenius (1592-1670), who was the first to find a scientific formulation for the concept of "pedagogical technology" in his work "The Great Didactic". In this work, J. A. Comenius detects ways and methods of teaching, which can guarantee the positive result. As a whole, Comenius' work is directed towards formulation of basic methods of teaching, which, in his opinion, can be similar to "proficiently tuned up mechanism, which is a didactical machine" (Коменский, 1939). He wrote, "For the didactical machine it is necessary to find:

1) firmly specified aims;

2) means, which are precisely adjusted to achieving the aims;

3) strict rules on usage of the means making it impossible not to reach the aims" (Коменский, 1939).

Thus, he was the first man who formulated the module "aim - means - rules of their usage - result", which is the core of any technology. Comenius' quest is still urgent in the modern pedagogy.

The term "pedagogical technology" developed in the $20^{\text {th }}$ century.

In the 1940s, the term "technology in education" meant application of engineering mind in teaching and education process and it was directly related to usage of audio and visual means in the study process. In 1946, pedagogical 
technologies were regarded as an object of research. In the international pedagogical encyclopaedia (Оксфорд, 1985) it is written that the reason of it was the introduction of the audio and visual education plan in Indiana University of the USA, and its author was L. Larson. Attempts to "technologize" the study process at that time were marked with appearance of various means of receiving information (starting with recording and reproduction of sounds to projection of images), combined under the term "audiovisual means" (cassette-recorders, TV-sets, record-players, projectors - objects of everyday use).

In the 1950s, a special "technological" approach to construction of the very process of teaching appeared, the theoretical basis of it became the idea of programmed learning. The conception of the idea was grounded by American psychologist B. Skinner (Burrhus Frederic Skinner, 1904-1990) in 1954 in his lecture "The Science of Learning and the Art of Teaching". The point of this approach is the idea of complete controllability of student's work. Particular features of this kind of teaching are specification of teaching aims and consequent procedure of their achievement - an element by element. W. Schramm (Wilbur Lang Schramm, 1907-1987) presented a more detailed content of the programmed learning - he believed that "the programmed learning is an automatic tutor, leading students a way consisting of small logically related steps, thus it almost does not make any mistakes and gives correct answers, which are immediately confirmed by communicating the outcome, and as a result it moves by subsequent steps towards the answer, which is the aim of learning (Schramm, 1997).

In 1958, American scientist and pedagogue N. Crowder (Norman Allison Crowder, 1921-1998) refined on B. Skinner's technology by putting forward a branched scheme of programmed learning with the multiple choice out of the suggested answers and with the corresponding feedback depending on the correctness of the answer. Thus, the teaching technology became adaptive, i.e. it ensured the possibility to vary ways of presentation of the study material depending on changes in internal or external conditions of teaching.

In 1961, B. Skinner's follower D. Finn suggested a new term - "teaching technology". In the University of South California he organised a department of teaching technology. D. Finn noticed that only "unsophisticated people think that technology is just a complex of hardware and teaching aids. It implies much more. It is a way of organisation, it is a way of thinking about materials, people, institutions, models and systems "man-machine" (Селевко, 2006).

The struggle between Skinner's and Crowder's followers in the 1960s ended with a compromise, which was called the "period of consolidation" (1967-1972). This is the time of popularity of various concepts and paradigms of pedagogical technologies, and the very problem obtained overall pedagogical significance. As a result, the combined technology of programmed teaching appeared, where two directions of its interpretation were defined in dependence of the level and 
results of research in the given sphere in various countries. Supporters of the first direction proceeded relating technologies with application of technical means in education (technology in education). Representatives of the second direction highlighted the necessity to increase efficiency of organisation of the teaching process (technology of education) and to overcome retarding of pedagogical ideas from the rapid technological development. Thus, the first direction was marked as "technical aids in education", the second one - "technology of education" or "technology of the education process".

Mass development and introduction of education technologies into practice in schools started in the 1960s-1970s in Europe and the USA and appears in works of B. Bloom, J. S. Bruner, B. Coscarelli, G. Caroll, D. Hamblin. The result of the given stage is recognition of pedagogical technologies as a research object and the increase of the number of universities working out their own curricula for preparation of specialists in the sphere of pedagogical technologies.

In the 1970s, the complex approach in teaching gave the possibility to solve didactical tasks, which can be described and defined in details. Pedagogical technologies were introduced almost in all countries.

The 1980s-1990s can be characterised as the extension of the base of the pedagogical technology. It was connected with the recognition of pedagogical technologies by the sphere of theoretical knowledge in pedagogy, where the concept of the "technology of education" began to prevail.

Russian academician G. Selevko distinguished three aspects in the "pedagogical technology":

- scientific: pedagogical technologies are a part of pedagogy, investigating and developing aims, content, teaching methods and projecting pedagogical processes;

- processually descriptive: the description (algorithm) of the process, the aggregate of aims, content, methods and means for achievement of the planned results of education;

- $\quad$ processually operative: realisation of the technological (pedagogical) process, functioning of all personal, instrumental and methodological pedagogical means.

Thus G. Selevko divides the structure of the pedagogical technology into 3 components: the conceptual part, the informative part and the processual part (Селевко, 2006).

In 1990, interactive technologies were applied and introduced into education. The problem of technologies became one of the most popular discussion topics in pedagogy. The scientific and pedagogical literature about pedagogical technology in education includes hundreds of items with dozens of interpretations of the meaning. Here are some of them. 
Pedagogical technology is:

- the systemised method of planning, realisation and assessment (devising - applying - assessing) of the entire process of learning and learning by taking into account human and technical resources and their interrelation. Technological effectiveness of the education process consists in making the education process completely manageable (Глоссарий терминов по технологии образования, 1986);

- $\quad$ a sphere of research and practice (in the frameworks of the education system), related to all aspects of organisation of pedagogical systems and the procedure of allocation of resources for achieving specific and potentially represent able outcomes (Митчелл, 2011);

- a complex, integrative process comprising people, ideas, means and ways of organisation of activities for analysis of problems and planning, ensuring, assessing and managing problem solution, embracing all aspects of assimilation of knowledge (Ассоциация по педагогическим коммуникациям и технологии США, 1979);

- a substantial technique of realisation of the education process (Беспалько, 1989);

- $\quad$ to the greatest extent interconnection with the study process - student's and teacher's activity, its structure, means, methods and forms (Селевко, 2006).

Thus the analysis of the given problem makes it possible to highlight the consistent line in the teaching approach: verbal - audio and visual programmed - interactive teaching, as well as the methodological principles of the pedagogical activity, if it is realised in the framework of one or another pedagogical technology:

- conceptuality (definition of aims, tasks, methods and content of education);

- $\quad$ systematic nature (a systematic approach in teaching and assimilation of knowledge taking into account interaction of technological and human resources);

- manageability (the possibility of diagnostic targeting or aim setting, planning, projecting, step diagnostics, variation of means and methods aiming at result correction, presence of the feedback);

- reproducibility (existence of methodological recommendations for realisation of technologies;

- efficiency and productivity (achievement of the aim, guaranteed achievement of the results by students).

Leading researcher of the given issue in Russia, academician of the Russian Academy of Education V. Bespalko wrote that "any activity can be either 
technology or art. Art is based on intuition, the technology is grounded on science. Everything starts with art and ends with technology in order to start all over again” (Беспалько, 1989).

The analysis of the scientific theoretical literature helped:

- $\quad$ to define the concept of "pedagogical technology" as a reasoned and detailed model of pedagogical activity, a way of realisation of the content of education, representing a system of forms, methods and means of learning, ensuring more efficient achievement of the aim;

- to determine the basic methodological principles of pedagogical technologies are defined, which are used to evaluate the pedagogical activity: conceptuality, systematic nature, manageability, reproducibility, efficiency and productivity.

\section{Activity as a basis of pedagogical technologies in music education}

The sphere of music education has been rather conservative for a long time and has almost not used technological innovations. Mostly it is connected with particularity of music education, which is directed towards emotions and individual's inner world, and its development is "unique, inimitable and cannot be technologically described” (Шакурова, 2016).

Nevertheless, in the beginning of the $20^{\text {th }}$ century active introduction of different pedagogical technologies started. Pedagogical technology in the music educational process is an instrument helping the pedagogue to reach the planned result in a more efficient manner, but the process of task solving becomes consistent, logical, reasoned and purposeful. This is a very important moment, because technological efficiency is one of characteristic features of a pedagogue's activity in the $21^{\text {st }}$ century.

During music studies fundamentals of systematisation, classification of phenomena, algorithms of creative thinking on the basis of perception and analysis of musical artistic characters are laid, thus defining development of students' memory, fantasy and imagination stimulating them to search for unusual problem solving ways. Development of these abilities is indispensable in any creative sphere of human activity, making person's life integral and interesting.

The basis for the choice of pedagogical technologies in music education should be separation of the music activity as a condition and a way, which makes it possible to organise interaction of the triad: the teacher - the student - music. The principal methodological base of the given affirmation is the activity theory (L.Vygotsky, S.Rubinstein, A.Leontyev). Thus according to S. Rubinstein "the very activity is the condition for the individual's development, but the music art as the only activity corresponding to the task of discovery, expression and communication of the personal sense of the reality, is the subject sphere, which 
assists the aspects defining the process of qualitative changes of the individual" (Рубинштейн, 2017).

\section{Aim Setting}

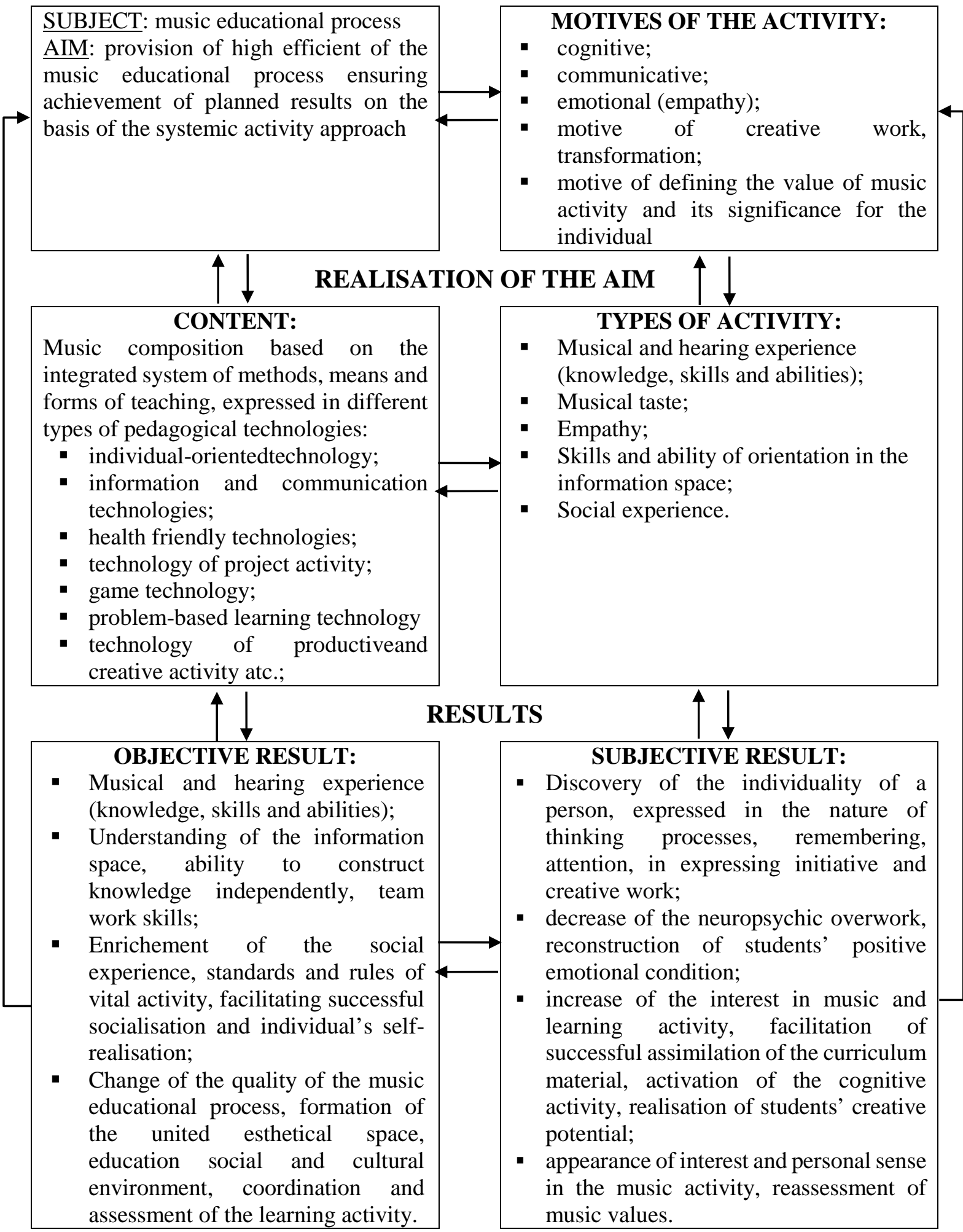

Figure 1. The Processual Model of Pedagogical Technologies in the Musical Educational Process as an Activity 


\section{The first step- aim setting}

The activity approach acts as a concrete scientific methodology for pedagogy. The main principles of the activity approach: the systematic character, the principle of development, objectivity, the cohesion of construction of external and internal activity, correlation and interconditionality of all structural components of the activity (Леонтьев, 1975).

Mutually conditioned and interrelated structural components of activity are: aims - tasks - motives - content and ways helping to realise the activity -planned results of the activity.

On the basis of Professor Z. Chehlova's activity cycle (Chehlova, 2002), the processual model of pedagogical technologies in the music education process as an activity was constructed (Figure 1).

The basis of the pedagogical technology is precise (diagnostic) definition of the final aim. The given stage is the interrelation between the pedagogue's aim and the student's motive, because the pedagogue's aim must be accepted by the student. The interest, motive (activity inducement), need in execution of the activity must arouse in the student, and as a result there will be the student's interest and personal sense in the given activity. In the music educational process this interrelation is realised with help of the following motives: cognitive, communicative, emotional (empathy), the motive of creative work and motive of defining the value of music activity and its significance for the individual.

\section{The second step - realisation of the aim}

At this stage the aim is being realised. The main content of the aim realization is the music composition based on the integrated system of methods, means and forms of teaching, expressed in different types of pedagogical technologies.Here are some of them.

\section{Technology of the productive and creative activity}

In the technology of productive and creative activity there should be a qualitatively new approach in selection of the content of the music artistic material. The new basic formation in the principle of selection of music works is in the technological approach "from the past to the present, from the present to the future" (Громова, 2017). Such an approach gives a possibility to consider every music work from the point of view of traditions and contemporaneity, but the productive and creative activity enables modelling its existence in the future. Thus, for instance, when analysing the genre of singer-songwriters (topic "Contemporaneity in music"), students learn about the history of appearance of 
this genre, they study music of medieval bards, minstrels and troubadours. In the process of learning modern song-writers' songs, students examine the genre from the point of view of the modern culture, and in the process of discussion they highlight the topics, which are interesting and important for teenagers, thus creating the base for music works of the future.

Special attention in the given technology is paid to the method of musical improvisation as a basis of productive and creative activity. This method is based on the interaction of the artistically figurative and constructive thinking. In parallel with it, one of the main features of the individual's psyche is being developed - it is fantasy, which is the principal component of the music artistic activity.

\section{Health friendly technologies}

Health friendly technologies are pedagogical technologies aimed at improvement and preservation of students' health (Лобанова, 2005).

It is experimentally proved that music can calm, remove irritability, tension, but it also can excite and stir up. Numerous works of classical music are included into the list, which was made on the basis of neurophysiological investigations of the influence of music characteristics on child's brain. For example, Mozart's melodies exert considerable influence on a human being.

Music perception, performance are the main forms of music therapy. Essentially every teacher of music is a spontaneous psychotherapist, changing students' mood and view of life with help of music. For instance, physicians say that stringed instruments are more efficient in treatment of heart diseases, and performance of joyful songs also helps heart patients. The clarinet improves functioning of blood vessels, the flute has got a positive influence on lungs and bronchus.

Singing folklore is the natural system of art-therapy, including cure with sounds, music, movement, drama, drawing and colour. Songs develop children's ear for music and memory, as well as lungs, breathing and speech apparatus. Hand relaxation, which is typical for dance folklore, enables removing cramps.

Owing to researchers of the psychophysiological aspect of music influence, it is possible to admit that the following facts have been ascertained:

- music influences noticeably the minute blood volume, heart rate, the blood sugar level;

- music stimulates emotions;

- music improves verbal and arithmetical skills;

- music stimulates processes of perception and memory;

- music activates creative thinking. 


\section{Information technologies}

Modern pedagogical technologies are unimaginable without wide usage of new information technologies. School studies on the basis of computer technologies are introduced into the learning process. Students' interest in modern computer systems is a motivating basis of the learning activity. Information technologies make it possible to discover pedagogical, didactical functions of methods; they become the fundamentals of the modern education, ensuring the necessary quality level, variety, differentiation and individualisation of teaching and upbringing (Бороздин, 2006).

There is a range of music computer software. It can be divided into the following groups:

- Music record-players;

- $\quad$ Software for karaoke;

- Music constructors;

- Music encyclopaedia;

- Software for studies;

- Software for improvisation, playing music in groups, music writing.

Every computer user knows the first group of software - this is Windows Media Player, WinAmp, etc. Possibilities of this software are rather wide: reproduction of music files, building lists of melodies, recording in different formats. In order to attract students' attention, to direct their thinking to the abstract and figurative side, the teacher can use Windows Media Player or WinAmp, where there are various lines, changing charts, which are moving along the music playing, drawing fancy designs. For vocal work it is possible to use such software as VocalJam or to write own composition with help of KarMaker.

Three dimensions, animation, video, sound, imitation of drawing techniques, interactivity of computer software makes it possible and more efficient to develop all types of perception and to involve all types of memory at a lesson: visual, hearing, motoric, figurative and associative. It significantly increases efficiency of the lesson and contributes to enlargement of subject interrelation, when presenting the material.

Application of computer technologies in the music educational process contributes to:

- students' personal development;

- $\quad$ increase of students' interest in music lessons;

- $\quad$ increase of interest in creative and cognitive activity;

- development of activity and independence;

- development of students' esthetical, emotional integrated attitude to music art; 
- development of the basics of students' theoretical thinking.

\section{The third step - result of the activity}

In the model there are subjective and objective results of the activity based on the correlation and interconditionality of all structural components of the activity.

The objective result:

- $\quad$ Musical and hearing experience (knowledge, skills and abilities);

- Understanding of the information space, ability to construct knowledge independently, team work skills;

- Enrichement of the social experience, standards and rules of vital activity, facilitating successful socialisation and individual's selfrealisation;

- Change of the quality of the music educational process, formation of the united esthetical space, education social and cultural environment, coordination and assessment of the learning activity.

The subjective result is contribution to:

- discovery of individuality of the person, expressed in the nature of thinking processes, remembering, attention, in demonstration of initiative and creativity;

- decrease of neuropsychic overwork, recovery of the students' positive emotional condition;

- $\quad$ increase of interest in music and the learning activity, facilitation of remembering the study material, activation of the cognitive activity, realisation of the creative potential of students;

- appearance of the interest and personal sense in the music activity, reassessment of music values.

\section{Conclusions}

1. The analysis of the scientific theoretical literature helped to define the concept of "pedagogical technology" as a reasoned and detailed model of pedagogical activity, a way of realisation of the content of education, representing a system of forms, methods and means of learning, ensuring more efficient achievement of the aim;

2. Basic methodological principles of pedagogical technologies are defined, which are used to evaluate the pedagogical activity: conceptuality, systematic nature, manageability, reproducibility, efficiency and productivity; 
3. The theoretical fundamentals for examination of pedagogical technologies in music education are the activity theory and the activity cycle, which became the basis for development of the processual model of pedagogical technologies in music education process as an activity;

4. The processual model of pedagogical technologies in the music educational process as an activity contributes to discovery of individuality of the person, recovery of the students' positive emotional condition, increase of interest in music and the learning activity, ability to orientate in the information space, enrichment of the social experience, and appearance of the interest and personal sense in the music activity and change of the quality of the music educational process, formation of the united esthetical space, education social and cultural environment, coordination and assessment of the learning activity.

\section{References}

Čehlova, Z. (2002). Izzinas aktivitāte mācībās. R.: RaKa.

Schramm, W. (1997). TheBeginningsofCommunicationStudyin America: A PersonalMemoir. ThousandOaks, CA: Sage.

Skinner, B. F. (1968). The Technology of Teaching. NewYork: Appleton-Century-Crofts.

Беспалько, В. П. (1989). Слагаемые педагогической технологии. Москва: Педагогика.

Бороздин, О. А. (2006). Применение музыкально-компьютерных технологий на уроках музыки в общеобразовательной школе. Музыка в школе, № 1, с.11.

Глоссарий терминов по технологии образования (1986). - Париж, ЮНЕСКО.

Громова, Е. А. (2017). Педагогические технологии и музыка. Научное сообщество студентов ХХІ столетия. Гуманитарные науки: сб. ст. по мат. ХХІХ междунар. студ. науч.-практ. конф. № 2 (29).

Дистервег, А. (1956). Избранные педагогические сочинения. Москва: Учпедгиз.

Каменский, Ян Амос (1939). Великая дидактика. Том 1 Государственное Учебнопедагогическое издательство Наркомпроса РСФСР.

Леонтьев, А. Н. (1975). Деятельность. Сознание. Личность. Москва: Политиздат.

Лобанова, Е. А. (2005). Возможности урока как средство реализации здоровьесберегающих технологий. Музыка в школе, № 3.

Митчелл, Д. (2011). Эффективные педагогические технологии специиального и инклюзивного образования. Редактор Наталья Барисова, изд. Перспектива.

Михайленко, Т. М. (2011). Игровые технологии как вид педагогических технологий. Материаль международной научной конференции, Челябинск, 140-146.

Рубинштейн, С. Л. (2017). Бытие и сознание. Редактор К. Абульханова - Славская, Издательство: Питер.

Селевко, Г. К. (2006). Энциклопедия образовательных технологий: В 2т. Т1. НИИ школьных технологий, (Серия „Энциклопедия образовательных технологий”).

Сластенин, В. А. (2007). Педагогика: учеб. пособие для студ.высш. учеб.заведений/ В.А. Сластенин, И. Ф. Исаев, Е. Н. Шиянов; под ред. В. А. Сластенина. 7-е изд., стер. Москва: Издательскийцентр „Академия”.

Фохт, Б. А. (1998). Педагогические идеи Сократа, № 1 (22), 60-64. 
Marchenoka, 2018. Pedagogical Technologies in Music Education as a Factor of Development of the Integral Personality

Шакурова, Н. Ш. (2016). Музыкальная педагогика: от традиции к инновации (некоторые теоретические аспекты). Журнал Вестник, № 1 (11), 71-74.

Эдвард де Боно (2005). Серьезное творческое мыиление, издательство Попури, перевод Д. Онацкая.

Эмерсон, Р. (2015). Сверхдуша. Журнал Вестник теософии, № 13. 